\title{
Kreatywność eksport-import. Interdyscyplinarne badania gospodarki kreatywnej w Europie Środkowo-Wschodniej
}

\author{
Karol Franczak \\ Uniwersytet Łódzki \\ DOI: http://dx.doi.org/10.18778/1733-8069.16.4.04
}

\section{Słowa kluczowe: gospodarka kreatywna, Europa Środkowo- Wschodnia, dyskurs modernizacyjny, relacje centrum- peryferie, zwrot translatologiczny}

\begin{abstract}
Abstrakt: Śledząc rozwój interdyscyplinarnych analiz gospodarki kreatywnej w refleksji społeczeństw zachodnich, tekst stawia pytanie o specyfikę implementacji tej idei w Europie Środkowo-Wschodniej. Autor konfrontuje mitologię przemysłów kreatywnych ze złożonym kontekstem społecznym i politycznym krajów regionu oraz próbuje ustalić, czy określone polityki publiczne mają porównywalny wynik, kiedy aplikowane są w różnych społecznych, kulturowych i politycznych warunkach. Problematyzacja „kompatybilności” dyskursu innowacjonistycznego z odmiennym od zachodniego typem społeczeństwa i nowoczesności służy refleksji nad uniwersalnym fenomenem recepcji zachodnich narracji modernizacyjnych, strategii ich przyswojeń, oporu lub nowych rekonstrukcji.
\end{abstract}

Karol Franczak, socjolog i kulturoznawca, adiunkt w Zakładzie Badań Komunikacji Społecznej Instytutu Socjologii UŁ. Zajmuje się problematyką władzy i komunikacji, sfery publicznej oraz analizą działalności współczesnych elit symbolicznych. Autor książki Kalający własne gniazdo. Artyści i obrachunek z przeszłościa (Universitas 2013). Publikuje w czasopismach naukowych oraz w pra- sie społeczno-kulturalnej, m.in. „Odrze” i „Tygodniku Powszechnym".
Adres kontaktowy:
Instytut Socjologii, Uniwersytet Łódzki
ul. Rewolucji 1905 r. nr 41, 90-214 Łódź
e-mail: karol.franczak@uni.lodz.pl 
Myślę, że świat jest zbudowany z kręgów wokół jednego miejsca. I że owo miejsce, zwane środkiem

świata, zmienia się w czasie - onegdaj były nim Grecja, Rzym, Jerozolima, a teraz bezsprzecznie jest to Francja, a właściwie Paryż. I można by cyrklem te kręgi wokół niego nakreślić. Zasada jest prosta: im bliżej środka, tym bardziej wszystko wydaje się prawdziwe i namacalne, im dalej zaś, tym mocniej świat jakby się rozłazi, jak zetlałe płótno w wilgoci. I jeszcze - ten środek świata jest jakby nieco uniesiony, tak że idee, mody, wynalazki, wszystko spływa zeń na boki. Najpierw nasiąkają tym bliskie kręgi, potem kolejne, lecz już słabiej, a do miejsc najdalszych dociera tylko mała część treści. [Tokarczuk 2018: 25]

I dea gospodarki kreatywnej - wiązana z kategoriami „ekonomii kultury”, „społeczeństwa wiedzy”, „innowacji” i "przemysłów kreatywnych" - w okresie dwóch ostatnich dekad stała się ważnym filarem narracji modernizacyjnej krajów Europy Środkowo-Wschodniej. Creative economy uważana jest za jeden z głównych filarów współczesnego rynku, którego siłę określają takie sektory, jak szeroko rozumiane projektowanie, usługi informatyczne, nowe media, gry komputerowe czy moda. Twórczość oraz styl pracy typowe dla wolnych zawodów definiuje się tu jako główny mechanizmem rozwojowy odpowiadający za generowanie innowacji oraz wzmacnianie konkurencyjności. Predyspozycje „klasy kreatywnej” gwarantować mają odporność na nieustanne zmiany w warunkach rosnącej niepewności zarówno systemu gospodarki, jak i szerszego otoczenia społecznego. Rewersem uprzedmiotowienia kreatywności w postindustrialnej gospodarce - o czym rzadko mówią entuzjaści przemysłów kreatywnych - stało się jednak odpolitycznienie działań twórczych i zneutralizowa- nie ich subwersywnego potencjału. Demokratyzacja talentu oraz podporządkowanie go wymianie ekonomicznej służy dziś gwarancji bezpiecznej i przewidywalnej formuły autonomii. Kreatywność wprzęgnięto bowiem w obręb subtelnych praktyk panowania przy jednoczesnym potraktowaniu twórczości jako obietnicy emancypacji współczesnych pracowników i rękojmi ich materialnego powodzenia.

Koncepcję gospodarki kreatywnej można rozumieć jako element jednego z wielu importowanych po 1989 roku do regionu projektów rozwojowych. Jest ona zgodna z dominującą od początku transformacji społeczno-gospodarczej strategią naśladowania państw zachodnich, ale jednocześnie konkurencyjna wobec identyfikacji z narracją skupioną początkowo wokół reform ,terapii szokowej” i implementacji wolnorynkowej wersji gospodarki kapitalistycznej, promocji przedsiębiorczości, kultu wzrostu gospodarczego oraz konkurencyjności, a następnie procesu akcesji do Unii Europejskiej i „modernizacji przez integrację”. Promując ideę gospodarki kreatywnej, jej współcześni adwokaci postulują odejście od wspieranego przez wcześniejsze narracje rozwojowe modelu przewag konkurencyjnych, opartego przede wszystkim na możliwie niskich zarobkach pracowników i budowie gospodarki w oparciu o inwestycje zagraniczne. Zamiast tego mówi się o walorach wiedzy, innowacji, rozwoju osobistego, konieczności nieustannych zmian oraz potrzebie generowania nowych rozwiązań, idei i projektów w celu wzmocnienia szans na długoterminowy wzrost. Zainteresowanie perspektywą jednostki, w tym jej psychologicznymi dyspozycjami, mentalnością oraz wyznawanymi wartościami, jest równie ważne co refleksja skupiona na kapitałowym i technologicznym wymiarze modernizacji. 
Choć idea gospodarki kreatywnej, wspomagana coraz liczniejszym towarzystwem projektów infrastrukturalnych, rości sobie prawo do performatywnego powoływania do życia rzeczywistości, którą retorycznie uzasadnia, jej „realność” w krajach postsocjalistycznych pozostaje wciąż pod dużym znakiem zapytania. Skłania to do postawienia tezy, że dyskurs creative economy jest obecnie ograniczony przede wszystkim do porządku uzasadnienia, czyli publicznie mobilizowanych zasobów interpretacji pożądanych przeobrażeń i nie stał się na razie porządkiem samej rzeczywistości, tworzącym reguły jej społecznej organizacji. Dziś dyskurs ten uzasadnia i legitymizuje preferowany kierunek zmian i trendów rozwojowych, a jego ekspansję traktuje się jako remedium na „braki” społeczeństw postsocjalistycznych i jednocześnie obietnicę wielkiej, cywilizacyjnej zmiany. W związku z tak sformułowaną tezą celem niniejszego tekstu jest, po pierwsze, zwrócenie uwagi na autokolonizacyjny wymiar, w dużym stopniu bezkrytycznej, implementacji dyskursów i praktyk definiowanych jako papierek lakmusowy postępu opartego na innowacjach. Po drugie, wskazanie na różnicę między oryginalnym kontekstem rozwoju gospodarki kreatywnej i rzeczywistością byłych demoludów. A po trzecie, wstępna charakterystyka przykładów lokalnych procesów translacyjnych związanych z typowymi dla regionu Europy Środkowo-Wschodniej strategiami implementacji i przyswajania dobrze zakorzenionej na Zachodzie idei.

\section{Wyzwanie interdyscyplinarności}

Natarczywe i wielokierunkowe promowanie idei gospodarki kreatywnej traktować można zarówno w kategoriach zagadnienia komunikacyjnego, jak i antropologicznego. Tak rozumiana formuła eksploracyjna nieuchronnie wiąże się z postępowa- niem interdyscyplinarnym, które obejmować może różne strategie analityczne - przykładowo - socjolingwistyczne badanie wzorów mówienia i pisania o gospodarce kreatywnej obecnych w komunikacji publicznej oraz antropologiczne badanie niedyskursywnych elementów rzeczywistości powiązanych $\mathrm{z}$ infrastruktura sektora kreatywnego i rozwojem innowacji.

W pierwszym przypadku za podstawową ramę teoretyczno-metodologiczną służyć może perspektywa jakościowej analizy dyskursu (Angermuller 2014; Martilla 2016; Langer, Nonhoff, Reisigl 2019). W jej optyce badanie przekonań o korzyściach płynących z upowszechnienia i promowania twórczych kompetencji pracowników rozumieć należy jako specyficzną odmianę dyskursu modernizacyjnego - kulturową konstrukcję wyłaniającą się ze specyficznego zorganizowania władzy i wiedzy (Foucault 2002). Wiązać to trzeba ze społecznie rozproszonymi relacjami panowania, które kierują publicznie formułowanymi wypowiedziami poprzez złożoną grę społecznych zasad, między innymi w obszarze wiedzy naukowej i popularnonaukowej, strategii lokalnych polityk publicznych, przekazów medialnych czy szeroko dostępnego poradnictwa.

Druga strategia badawcza współczesnego imperatywu kreatywności wykracza poza dyskurs rozumiany jako względnie uporządkowany obszar wypowiedzi. Przykładowo Andreas Reckwitz (2017) i Angela McRobbie (2016), niezależnie od siebie, stosują kategorię dyspozytywu kreatywności (Kreativitätsdispositiv, dispositif of creativity) jako z jednej strony rozwinięcie pojęcia dyskursu, z drugiej jako koncepcyjną i metodologiczną alternatywę. Analiza dyspozytywu również wywodzi się z dorobku Michela Foucaulta, który za pomocą tego terminu próbował opisać zmiany społeczne następujące 
w reakcji na „określony stan nagłej konieczności”, na przykład nową sytuację geopolityczną, gwałtowne zmiany demograficzne, pojawienie się nowych sposobów gospodarowania i związanych z nimi nowych wzorów życia czy wyczerpanie się i nieefektywność określonych metod rządzenia populacją (Bührmann, Schneider 2008; Nowicka 2016). W tym kontekście monodyscyplinarne badania obszaru gospodarki kreatywnej mogą być uważane za niewystarczające, ponieważ projekt przyspieszenia modernizacyjnego, będący odpowiedzią na ów krytyczny moment, ujawnia się zarówno w zestawie wzajemnie powiązanych składników dyskursowych (publicznych wypowiedziach, tekstach, dokumentach, oświadczeniach, regulacjach prawnych) i niedyskursowych (np. sposobach organizacji przestrzeni, kształcie i strukturze instytucji, rozwiązaniach instytucjonalnych i innych społecznych artefaktach), czyli zarówno w tym, co wysłowione, jak i w tym, co niewysłowione.

Potencjał uzupełniających badań antropologicznych łączyć można zatem z szansą pogłębienia analiz nad gospodarką kreatywną rozpatrywaną w postaci względnie nowych i zwykle nieproblematyzowanych form rządzenia populacją, które ograniczone zostają często do wymiaru tekstów i wypowiedzi. Dzięki instrumentarium analizy dyspozytywu możliwe jest między innymi badanie innych praktyk i artefaktów, które uznać można za społeczny kontekst dla narracji modernizacyjnych skupionych wokół kreatywności. Ideę gospodarki kreatywnej odnajdziemy oczywiście w dyskursie, ale też w niedyskursywnych rozwiązaniach organizacyjnych - na przykład w projektach przestrzeni „sprzyjającej inspiracji i rozkwitowi współpracy". Mimo że w refleksji nad architekturą od dawna mówi się o jej ścisłym powiązaniu z władzą (Sudjic 2015), to w publicznie formułowanych wyobrażeniach o śro- dowisku pracy „klasy kreatywnej” dominują narracje skupione wokół jego rzekomo emancypacyjnego potencjału. „Architekturę kontroli" - łączoną często z modernistycznym funkcjonalizmem i typowymi dla niego biurami - przeciwstawia się tu „architekturze wyzwalającej energię i kreatywność", która ma służyć uwłasnowolnieniu nowoczesnych czy ponowoczesnych podmiotów (Polyák 2010: 30).

Podążając tym tropem, warto krytycznie przyglądać się między innymi sposobom organizowania „infrastruktur innowacji” (,inkubatorom przedsiębiorczości", specjalnym strefom ekonomicznym, centrom kultury i sztuki, „kreatywnym klastrom”, office inspiration centers), nowym strukturom „oddolnej" gospodarki (networkingowi, co-workingowi, przestrzeniom początkujących start-upów, lokalom dla „kreatywnych”, infrastrukturze telepracy) czy strategiom rewitalizacji architektury postindustrialnej i sposobom tworzenia „kreatywnego miasta" (w tym towarzyszacym im procesom gentryfikacji). Wszystkie te przykłady łączyć mają kreatywność kulturalno-artystyczną z kreatywnością technologiczno-gospodarczą, a definiowana w ten sposób przestrzeń pomagać ma, mówiąc językiem jej promotorów, w „emancypacji życia zawodowego”, „wyzwalaniu inwencji”, „uruchamianiu ukrytych energii", "otwarciu umysłu”, „Współtworzeniu kreatywnego szumu" czy budowie twórczej atmosfery przy „minimum biurokracji”. Pogłębione badania antropologiczne przestrzeni ",kreatywnego ekosystemu” dają szansę na pokazanie, że - mimo obietnic - nie są to miejsca „zorientowane na wolnośćc.

\section{Dylematy imitacji}

Przy pobieżnym oglądzie projekty gospodarki kreatywnej realizowane w Europie Środkowo- 
-Wschodniej zdradzają istotne podobieństwo do losów powojennego projektu modernizacji socjalistycznej. Oba modusy rozwojowe łatwo połączyć z możliwymi pułapkami strategii imitacji - naśladowaniem i przyjmowaniem idei z obszarów definiowanych w danym momencie jako "centrum”. W przypadku polskich komunistów kierunek inspiracji jest tylko pozornie prosty. Choć w oficjalnej retoryce wzorowano się na rozwiązaniach aplikowanych w Związku Radzieckim i innych „bratnich państwach" bloku wschodniego, to w zasadzie była to „imitacja modernizacji imitacyjnej” (Musiał 2013: 196), naśladowanie projektu, który sam uwiedziony był zachodnim oświeceniem i wyrastającym z niego ideami przebudowy społecznej. Była to wizja postępu wspartego na przyspieszonej industrializacji, nakazowym charakterze strategii inwestycyjnych, rozwoju przemysłu i budowie fabryk nastawionych na masową produkcję. Postęp łączono z szybkim wzrostem PKB, zwiększeniem konsumpcji i zmianą struktury społecznej, w której coraz mniejszą rolę miała odgrywać ludność wiejska. „Jest ironią losu, że ZSRR, który od początku próbował zbudować społeczeństwo będące antytezą kapitalizmu, tworząc pierwsze modele radzieckiego systemu produkcji, inspirował się wynalazkami Henry'ego Forda, jednego z pionierów amerykańskiego kapitalizmu", pisała Elizabeth Dunn (2017: 25). Innym paradoksem było systematyczne ograniczanie przez partię historycznie proletariacką autonomii i podmiotowości robotników, w odniesieniu do których z powodzeniem wdrażano socjalistyczny wariant „zarządzania naukowego" i lokalną odmianę taylorowskich technik dyscyplinarnych.

Warto przypomnieć, że również idea centralnej kontroli planowania nie zrodziła się w wyobraźni polityków zza żelaznej kurtyny. Środkowoeuropejska nomenklatura dokonała „twórczego" przyswo- jenia dominującego ówcześnie modelu organizacji przemysłowej i preferowanej filozofii zarządzania. Z tego powodu trudno mówić tutaj o wiernym zapożyczeniu. Odstępstwa od wzoru zachodniej modernizacji były oczywiste. Kiedy ścisłego pozornie planu nie udawało się zrealizować, zastępował go subiektywizm „ręcznego sterowania” i improwizacja w pozyskiwaniu potrzebnych do produkcji komponentów (a czasem po prostu towarów „pierwszej potrzeby"). Znakiem firmowym gospodarek socjalistycznych było, poza tym, „uspołecznienie środków produkcji", rządowe uregulowanie każdego aspektu działania państwowych przedsiębiorstw czy całkowita kontrola oficjalnych zarobków oraz cen. W Polsce, mimo początkowego dystansu wobec stalinowskiego modelu gospodarki i wiary w możliwość obrony różnych form praw majątkowych, wygrał też - podobnie jak w innych komunistycznych krajach regionu - model dyskryminujący własność prywatną (z ważnymi dla późniejszej transformacji odstępstwami w rolnictwie). „Fordyzm i państwowy socjalizm posługiwały się tym samym projektem modernizacyjnym, jednak skończyły jako dwie różne nowoczesności. Prowadziło to do radykalnie odmiennego doświadczenia pracy i sprawiało, że robotnicy w tych systemach byli konstruowani jako osoby różnego typu", podsumowywała wizję tych różnic Dunn (2017: 36).

Tabuizacja rynku sprawiła, że podstawowym kryterium rozstrzygającym o dostępie do środków produkcji i pożądanych dóbr konsumpcyjnych były stosunki władzy na kolejnych szczeblach administracji publicznej. Adam Leszczyński wskazuje za Jánosem Kornaiem (1992) - autorem wpływowej krytyki gospodarki planowej sformułowanej $\mathrm{w}$ The Socialist System: The Political Economy of Communism - że nie pozwoliło to formacji nakazowo-rozdzielczej rozwinąć wystarczającego dla konkurowania 
z Zachodem poziomu innowacyjności. „Modernizacja komunistyczna była imitacyjna, energochłonna i powielała model, który na Zachodzie od lat siedemdziesiątych stawał się już przeżytkiem, a kluczem do niej był system polityczny, który ją stworzył i był z nią nierozerwalnie związany", stwierdzał Leszczyński (2013: 361-362). W konsekwencji anachronizmem okazał się również fetysz liniowego wzrostu, który w długiej perspektywie pozwolić miał na „dogonienie Zachodu". Stosunkowo wcześnie, bo już w siódmej dekadzie ubiegłego wieku, zdano sobie sprawę z tego, że kraje socjalistyczne skazane są na nieskończone „deptanie po piętach” krajom kapitalistycznym bez szans na przełomowy "skok w nowoczesność" i osiągnięcie statusu równorzędnego partnera. Wysiłek wynikający z idealizacji rozwoju w wersji praktykowanej przez Zachód odwzorowywał - nawet jeśli w sposób niezamierzony - dawną logikę kolonialną (Leszczyński 2013: 40), skłaniał bowiem do przyglądania się sobie w oparciu o miary zachodniego hegemona i poszukiwania wielkości dystansu między „nami” a „nimi”. Mitologizacja nowinek technicznych dostępnych "tam” - choćby tak banalnych jak zmywarki, maszyny ksero, magnetowidy czy pierwsze komputery - tylko to poczucie podrzędności mieszkańców Europy Środkowo-Wschodniej utwierdzała.

Dyskurs modernizacyjny oparty na instrumentalizacji i optymalizacji kreatywności ma również charakter naśladowczy. Jest to zresztą cecha każdej formułowanej po 1989 roku narracji transformacyjnej. Współczesna hipertrofia retoryki „ekonomii kultury” „kreatywności” i ,innowacji” to w dużym stopniu echo idei, działań i rozwiązań instytucjonalnych wdrażanych na Zachodzie przynajmniej od połowy lat 90. ubiegłego wieku. Aktorzy społeczni afirmujący dzisiaj publiczne programy kreatywności w Europie Środkowo-Wschodniej zaciągają dług w dorobku i politykach publicznych rządów Wielkiej Brytanii, Australii, Hiszpanii czy Stanów Zjednoczonych. Główną inspiracją pozostają tu działania brytyjskich laburzystów, którzy w latach 90. ubiegłego wieku uczynili z kreatywności jeden z atrybutów „trzeciej drogi”. Dla popularyzacji tej idei ważna była także między innymi turystyka miejska Baltimore i Barcelony, deindustrializacja Emscher Park w Essen i stworzenie w zniszczonym regionie górniczym obszaru eko-turystyki oraz centrum designu, australijska strategia "Creative Nation” czy programy Unii Europejskiej (m.in. „Culture 2007-2013" i „Creative Europe"). Istotną inspiracją okazały się także nośne koncepcje intelektualne na czele z „klasą kreatywną”, „kreatywnym miastem”, entertainment economy, experience economy czy turystyką kulturalną.

W historii rozwoju Cultural and Creative Industries (CCI) - głównej emanacji gospodarki kreatywnej pokusa podążania utartymi ścieżkami bywa zwykle bardzo silna, ulegają jej albo odpowiedzialne za ogólnokrajowe programy rozwojowe rządy centralne, albo uwiedzione ideą "kreatywnych klastrów” i „inkubatorów przedsiębiorczości” lokalne samorządy. Jak pisze Andy Pratt (2009: 10 [tłum. własne]), „w polu polityki publicznej CCI stawka jest wysoka, i presja, aby robić to, co inni już wcześniej zrobili albo naśladować politykę zaadaptowaną $\mathrm{w}$ innych sektorach, jest bardzo atrakcyjne". Przemysły kreatywne - obejmujące między innymi film, telewizję, design, modę, działalność wydawniczą, architekturę, sztuki wizualne i performatywne, nowe media i gry komputerowe, reklamę - zyskały status pozornie łatwo aplikowalnego modelu. Dziś wzorzec ten coraz łatwiej krytykować z użyciem argumentów piętnujących politykę bezpośredniego wdrażania obcych rozwiązań czy - po prostu - ich wulgarnego kopiowania. 
Mimetyczny charakter modernizacji opartej na kreatywności lokować zatem można w kontekście współczesnych relacji centroperyferyjnych, w których Europie Środkowo-Wschodniej przypada w udziale rola lojalnych wobec standardów Pierwszego Świata półperyferii. Paradoksalnie, rozpad na początku lat 90. XX wieku dwubiegunowych zależności geopolitycznych pchnął kraje regionu na ścieżkę jednostronnego naśladowania działań rozwojowych, których wzorce widziano prawie wyłącznie $\mathrm{w}$ krajach zachodniego rdzenia. „W świecie jednobiegunowym - stwierdza Andrzej W. Nowak (2016: 103) - półperyferie przestały pełnić funkcję Drugiego Świata, stając się jedynie elementem modernizacji imitacyjnej".

Kwestią sporną pozostaje, jak duże znaczenie miał w realiach powojennych ówczesny Drugi Świat i w jakim zakresie odmienna od dzisiejszej była sytuacja Polski i innych krajów Ostbloku w globalnym obiegu narracji modernizacyjnych. Wciąż dyskusyjne jest, na ile skutecznie państwa te były w stanie poszukiwać możliwości relatywnie niezależnej współpracy międzynarodowej obok dwóch głównych hegemonów - radzieckiego i amerykańskiego. Ilustracją przekroczenia podziału między konwencjonalnie pojmowanym „centrum” a „peryferiami”, a także dowodem względnej samodzielności w dystrybucji wiedzy i odpowiedzialnej za rozwój technologii, mogą być ówczesne relacje satelitów ZSRR z globalnym Południem, także w obszarze praktyk, które dziś uważa się za filary gospodarki kreatywnej. Dobrym przykładem są tu badania nad transferem w latach 50. i 60. polskiej wiedzy architektonicznej i urbanistycznej do krajów Afryki i Bliskiego Wschodu, nazywanych ówcześnie krajami Trzeciego Świata (Stanek 2015a; 2015b).

Warto podkreślić, że w połowie ubiegłego wieku to określenie nie miało tak jednoznacznie pejoratyw- nego wydźwięku jak dziś. W polityce zagranicznej krajów Europy Środkowo-Wschodniej wskazywało ono nie tyle na definiowaną w sposób jednostronny kulturową i ekonomiczną przepaść między krajami rozwijającymi się a "dojrzałym” i „rozwiniętym” Zachodem, co na alternatywny kierunek aktywności gospodarek pozostających za żelazną kurtyną. Tak pożądany przez kraje postkolonialne transfer "kreatywnego" know how z bloku socjalistycznego wynikał jednak nie tyle z życzliwie pojmowanej pomocy rozwojowej (np. chęci przeszczepienia do krajów Bliskiego Wschodu doświadczeń z odbudowy polskich miast po zniszczeniach wojennych), co z możliwości asymetrycznego drenażu odległej, ale dostępnej dla krajów Europy Środkowo-Wschodniej prowincji, i zaznaczenia swojej obecności w miejscach, gdzie toczyły się istotne gry głównych światowych mocarstw (Nowak 2016: 89; Zarycki 2016: 106). Tę swoistą misję cywilizacyjną, realizowaną na miarę możliwości wschodnioeuropejskich półperyferii, można też za Sorinem Antohim nazwać "geokulturowym bovaryzmem" (Judt 2013: 312) pragnieniem zajęcia lepszego miejsca na światowej mapie prestiżu i poważania, niż wskazywałyby na to makroekonomiczne wskaźniki rozwoju i jakości życia w społeczeństwach socjalistycznych.

Po 1989 roku Mitteleuropie nie udała się budowa autonomicznego bieguna wzrostu, mimo uruchomienia kilku ważnych z lokalnej perspektywy projektów - od politycznej koncepcji Grupy Wyszehradzkiej i Środkowoeuropejskiego Porozumienia o Wolnym Handlu (CEFTA), przez silnie zinstytucjonalizowane Trójmorze i Inicjatywę Środkowoeuropejską, po współczesne inkarnacje przedwojennej doktryny Międzymorza - polityczno-gospodarczego sojuszu państw leżących w obszarze między Bałtykiem, Adriatykiem i morzem Czarnym. Krajom tego obszaru nie udało się wypracować przewagi 
poprzez redefinicję ambiwalentnego położenia, które w przeszłości sprzyjało przede wszystkim dominacji Niemiec i Rosji. Im silniej w ostatnich trzech dekadach wybrzmiewał postulat solidarności państw Europy Środkowo-Wschodniej, tym mocniej kolejne przyjmowane z Zachodu jako pewnik modele modernizacyjne pogłębiały zależność regionu od krajów centrum. Jedno z ostatnich w tym łańcuchu ogniw zajmuje idea społeczeństwa wiedzy i wyrosła z niej koncepcja gospodarki kreatywnej. Warto rozważyć, dlaczego akurat ten model spotkał się $\mathrm{z}$ tak silnym odzewem, i to pomimo toczącego się od początku transformacji ustrojowo-gospodarczej sporu zwolenników i przeciwników integracji z zachodnioeuropejskim rdzeniem.

\section{Walka z ,zacofaniem”}

Dyskurs kreatywności, jeśli rozumieć go jako jeden z przykładów projektu innowacjonistycznego (Zarycki 2014), z powodzeniem odpowiedział na potrzebę reform kulturowych, które miałyby gwarantować rozwój nowych technologii i uniknięcie tak zwanego dryfu rozwojowego. W Polsce ostatnich lat dyskusje na ten temat orbitowały wokół przekonania o wyczerpującym się modelu gospodarczym, którego filarami od początku transformacji miały być inwestycje zagraniczne, stosunkowo niskie płace pracowników i systematycznie malejące znaczenie związków zawodowych (Jasiecki 2016: 62). Dużą popularność wśród komentatorów podejmujących w sferze publicznej temat gospodarczej peryferyjności Polski zyskała tym samym kategoria „pułapki średniego dochodu", której ryzyko problematyzują od dłuższego czasu tak politycy, ekonomiści czy socjologowie, jak i wielu dziennikarzy, i to niezależnie od identyfikacji politycznej czy światopoglądowej. Zakłada się tu, że pułapka średniego dochodu grozi gospodarkom, które w porę nie przestawią się z imi- tacyjnego modelu wzrostu na model innowacyjny i akumulację technicznie zaawansowanego kapitału (zob. Radło, Ciesielska 2013; Pruchnik, Zowczak 2016; Sieroń 2019).

Postulat uniknięcia „pułapki średniego dochodu” wpisuje się w dyskusję o źródła współczesnych problemów rozwojowych krajów półperyferyjnych. Myślenie w kategoriach innowacjonistycznych szczególnie dobrze uprawomocnia tak zwane wyjaśnienia kulturalistyczne, które $\mathrm{w}$ odniesieniu do regionu Europy Środkowo-Wschodniej uzyskały rzadko kwestionowaną prawomocność (Zarycki 2015). W optyce tak rozumianych wyjaśnień obciążającym residuum, które należy zidentyfikować i wykorzenić, aby zdynamizować rozwój, jest przypisywana mieszkańcom krajów rozwijających się specyficzna mentalność. Jednym z dogmatów od lat pozostaje tu przekonanie, że lekiem na psychologiczne „zacofanie” mają być odważne reformy kulturowe, gwarantujące przemianę kompetencji cywilizacyjnych współczesnych obywateli - przebudowanie ich „infrastruktury psychologiczno-mentalnej". W Polsce wniosek ten od wielu lat konsekwentnie stawia między innymi Jan Szomburg (2014: 146):

Są więc w sumie trzy główne składniki modernizacji: składnik materialny (infrastruktura techniczna i urządzenia), składnik instytucjonalno-regulacyjny oraz najważniejszy z nich - kulturowo-kompetencyjny, który sprawia, że dwa pozostałe mogą dobrze działać. (...) Warunkiem odniesienia długofalowego sukcesu modernizacyjnego i wyrwania się Polski z peryferyjności są wszystkie trzy płaszczyzny modernizacji, a nie tylko ta jedna - techniczna, na której w tej chwili jest skupiona uwaga rządu i opinii publicznej. Tylko wówczas będziemy w stanie przejść od 
gospodarki poddostawców i imitatorów konkurujących niskimi kosztami pracy do gospodarki opartej na kreatywności i wiedzy, dającej ludziom wysokie dochody i więcej czasu wolnego.

Konieczność przeprowadzenia „reformy kulturowej" postulowano niemalże od razu po przemianach 1989 roku, co uzupełnić miało transformację gospodarki w jej wymiarze materialnym i organizacyjnym - poczynając od wymiany parku maszynowego i przyswojenia nowych form produkcji, przez prywatyzację nierentownych przedsiębiorstw państwowych, na poszukiwaniu nowych sposobów inwestowania kończąc. W ocenie promotorów zmian towarzyszących transformacji konieczna była praca nad powołaniem do życia nowego typu pracownika, a nawet więcej - stworzenie nowego typu osobowości. Te swoiste wysiłki reedukacyjne dotykające zarówno szeregowych pracowników fizycznych, jak i pionu menedżerskiego uznać można za istotny pierwiastek przebudowy gospodarczej lat 90., co wyczerpująco opisała przywoływana już wcześniej Elisabeth Dunn (2017). Analiza praktyk modernizacyjnych firmy Alima-Gerber w dobitny sposób ukazuje dominujące $\mathrm{w}$ tamtym czasie przekonanie reformatorów, jak bardzo „powodzenie w tworzeniu gospodarki rynkowej wymaga zmiany samych podstaw tego, co to znaczy być osobą" (Dunn 2017: 20).

Dziś zrozumienie dla tak formułowanego aksjomatu odpowiada między innymi za promocyjny i biznesowy sukces projektów mających zasypywać deficyty kapitału społecznego czy wspomagać rozwój kompetencji w obszarze twórczości. W tej optyce źródłem pożądanej przemiany jest przede wszystkim poszerzenie ukierunkowanego rynkowo zasobu kulturowego i wzmocnienie odpowiedniej postawy psychologicznej. Oba obszary - przy przy- jęciu optyki innowacjonistycznej - w całej populacji noszą ciągle znamiona „niedorozwoju”, „upośledzenia” i „dysfunkcjonalności”. Przyrost pożądanych $\mathrm{z}$ tego punktu widzenia i definiowanych jako „właściwe” kompetencji cywilizacyjnych blokować ma szereg czynników, których zasięg analizuje się w zależności od przyjętej perspektywy czasowo-historycznej - od obciążeń identyfikowanych z kulturą szlachecką (długie trwanie kultury folwarcznej, relacje pracownicze oparte na pamięci pańszczyzny i szarwarku), przez spuściznę komunizmu (amputacja "ducha inicjatywy", syndrom homo sovieticus, postawa wyuczonej bezradności), po dziedzictwo heroicznego okresu transformacji (ułomna przedsiębiorczość, brak przebojowości, roszczeniowość, nieumiejętność przystosowania się do zmiennych warunków rynku pracy).

Przypominając najważniejsze argumenty krytyki ujęć kulturalistycznych, Tomasz Zarycki (2015: 64) dowodzi, że w przeszłości wielokrotnie

[w]skazywano zarówno na ich funkcję legitymizacji nierówności wewnątrz społeczeństw (w szczególności dominacji wielkiego kapitału czy klas wyższych mających możliwość definiowania kryteriów kulturowej innowacyjności i deprecjonowania jej konkurencyjnych form), jak i nierówności międzynarodowych (dominacji krajów rdzenia nad wiecznie "goniącymi" je peryferiami). Hegemonia rdzenia wobec peryferii jawi się w świetle innowacjonistycznych, a szerzej kulturalistyczno-psychologicznych dyskursów, jako zawiniona prawie wyłącznie przez moralne lenistwo tej ostatniej. Skoro głównym czynnikiem konkurencyjności okazuje się dziś innowacyjność, a więc zasób kulturowo-psychologiczny, to mobilizacja w tym wymiarze jest nie tyle kwestią ekonomiczną, ale przede wszystkim kwestią woli i wiedzy. 
Postulaty przekroczenia tak rozumianych barier formułowane są zazwyczaj w izolacji od geopolitycznego kontekstu i miejsca Europy Środkowo-Wschodniej w międzynarodowym podziale pracy. Zwolennicy kulturowego i psychologicznego sposobu definiowania wyzwań rozwojowych przemilczają zazwyczaj rolę globalnych struktur kapitałowych w odtwarzaniu nierówności i podtrzymywaniu ekonomicznego podporządkowania krajów Europy Środkowo-Wschodniej krajom zachodniego rdzenia. Objaśnienia kulturalistyczne bagatelizują najczęściej znaczenie wielopokoleniowych procesów akumulacji aktywów ekonomicznych w krajach modernizacyjnego centrum oraz rolę krajów półperyferyjnych w procesach gromadzenia jego bogactwa.

Do argumentów podważających sens analityczny oraz wartość poznawczą kulturowych wyjaśnień rozwoju gospodarczego sięga też Ha-Joon Chang (2016). Jego analiza drogi przebytej między innymi przez Koreę Południowa, Chiny, Japonię, Irlandię, Finlandię czy antenatów dzisiejszych Niemiec ujawnia ambiwalentne znaczenie kultury dla sukcesu modernizacji i świadczy przeciw fatalizmowi myślenia esencjalistycznego. Przeczucie, że kulturowe wyjaśnienia rozwoju gospodarczego skrywają cywilizacyjny suprematyzm Chang odnajduje już w latach 60. XX wieku i rozwijającej się ówcześnie wrażliwości postkolonialnej (2016: 318). Dowodzi, że kultura zmienia się wraz z rozwojem gospodarczym, nie jest zatem ani przekleństwem (tam, gdzie jej rzekomo niezmienne cechy hamują rozwój), ani gwarancją ciągłego powodzenia (w sytuacji jakoby trwałego nabycia wartości odpowiadających za przedsiębiorczość i innowacyjność).

Pouczającą ilustracją omawianą przez Changa jest ambiwalentne znaczenie konfucjanizmu i jego kontrfaktyczne wykorzystanie w tłumaczeniu historycznych sukcesów lub porażek Państwa Środka. Z jednej strony dominująca w Chinach doktryna moralno-polityczna współtworzyć miała rozwój kultury, która stoi za niekwestionowanymi osiągnięciami gospodarki ostatnich dekad. $Z$ takimi cechami jak pracowitość, spolegliwość wobec władzy, wiara w wartość edukacji i promowanie współpracy jako sposobu realizacji wspólnego celu. Jednakże w przeszłości odwołania do konfucjanizmu służyły czemuś przeciwnemu - wyjaśnianiu zarówno cywilizacyjnego regresu w mniej chwalebnych okresach cesarstwa, jak i wolnego tempa rozwoju Chińskiej Republiki w drugiej połowie XX wieku. Konfucjanizm miał dusić kreatywność i przedsiębiorczość z uwagi na pielęgnowanie sztywnej hierarchii społecznej, zamykanie dróg awansu dla ludzi spoza tradycyjnej elity, żądanie wąsko pojmowanej lojalności i powiązaną z tym afirmację tradycyjnych autorytetów. „Ta zabawa w Jekylla i Hyde'a pokazuje nam, że nie ma kultury, która byłaby całkowicie jednoznacznie dobra lub zła dla rozwoju gospodarczego. Wszystko zależy od tego, co ludzie robią z «surowcem» ich kultury", pisze Chang (2016: 328). Jest przekonany, że w procesie rozwoju gospodarczego ulega ona reorganizacji, a to pozwala pracownikom mniej lub bardziej spokojnie adaptować się do zachodzących zmian.

W takiej optyce trudno bronić tezy, że określone dyspozycje psychologiczne - na przykład lenistwo, oszczędność, pracowitość - uznać trzeba za dominującą cechę wybranej wspólnoty. Przypisywanie niechęci do pracy obywatelom społeczeństw biednych to jeden z wariantów tego rodzaju błędnego założenia. Ludzie wykonują swój zawód w określony sposób głównie za przyczyną warunków ekonomicznych, a nie rzekomo trwałych dyspozycji uformowanych w kontekście generującym „pożąda- 
ne” lub „niepożądane” cechy kulturowe. Zdaniem Changa rozwój gospodarczy może przewrócić na nice dotychczasowe przyzwyczajenia czy utrwalone sposoby postępowania pracowników i sprawić, że nowo nabyte wartości zwrotnie wzmocnią wysiłek modernizacyjny, który z pozoru wydawał się obcy dominującej $w$ danym środowisku mentalności. Powolna dynamika rozwoju gospodarczego nie jest zatem klątwą rzuconą na społeczeństwo definiowane $\mathrm{w}$ danym czasie jako zapóźnione.

To, że kultura zmienia się o wiele szybciej, niż zakładają kulturaliści, powinno budzić w nas nadzieję. Negatywne cechy zachowania, takie jak lenistwo czy brak kreatywności, hamują rozwój gospodarczy. Jeśli cechy te są w pełni, albo choćby w znacznej mierze, zdeterminowane kulturowo, to potrzebna byłaby „rewolucja kulturalna”, aby się ich pozbyć, zanim moglibyśmy zacząć rozwój gospodarczy. Jeśli potrzebowalibyśmy rewolucji kulturalnej, zanim będziemy mogli rozwinąc gospodarkę, to rozwój gospodarczy byłby prawie niemożliwy, bo rewolucje kulturalne udają się rzadko, jeśli w ogóle. (Chang 2016: 334-335)

Rewersem dyskursu psychologiczno-mentalnościowego w realiach Europy-Środkowo-Wschodniej jest diagnoza innej postaci „zacofania”, to jest rzekomego niedostosowania społeczeństw regionu do nowych wyzwań gospodarki przemysłowej i typowych dla niej dominujących form pracy. Te ostatnie okazują się problematyczne w świetle alternatywnych celów rozwojowych i definiowane są w kategorii przeszkody na drodze udanej implementacji praktyk mających być motorem modernizacji. W 2003 roku w Wilnie Chris Smith - w pierwszym rządzie Tony'ego Blaira szef superministerstwa Department for Culture, Media \& Sport, a zarazem jeden z głównych promotorów gospodarki kreatywnej - mówił:
Wierzę, że żyjemy w czasach nowej gospodarczej rewolucji w zaawansowanych gospodarkach Europy. Przez stulecia przeszliśmy od gospodarki opartej na rolnictwie, przez dominację produkcji przemysłowej, po gospodarkę usługową. Wierzę, że w tym momencie zaczynamy przechodzić od czystej gospodarki usługowej do gospodarki ufundowanej mocno na kreatywności. I jest to sytuacja nie tylko gospodarek takich państw jak Wielka Brytania, która od wielu lat budowała przewagę w oparciu o sektor przedsiębiorczości. Mam wrażenie, że jest to także sytuacja krajów rozwijających się. (za: Tomić-Koludrović, Petrić 2005: 7)

Słowa Smitha odwzorowują typową dla relacji centroperyferyjnej retorykę misjonarską - wypowiedź brytyjskiego ministra brzmi jak nowa wersja „dobrej nowiny” połączona z protekcjonalnym „nawracaniem na «kreatywność»" dalekiej prowincji. Przy okazji Smith punktuje wskaźniki współczesnego „zacofania" i rysuje przed partnerem z „nowej Europy" klarowne cele modernizacyjne. Nie ma wątpliwości, że dla diagnozowanej tu utraty przez sektor przemysłowy gospodarczego znaczenia nie ma alternatywy i podstawowym trendem postindustrializacyjnym musi być rozwój gospodarki kreatywnej.

Wypowiedź Smitha i sposób jej odbioru wśród establishmentu polityczno-gospodarczego krajów regionu ujawniają jeszcze jedną osobliwość imitacyjnego procesu transformacyjnego na gruncie Europy Środkowo-Wschodniej. Jest nią bezkrytyczna akceptacja przez lokalne elity symboliczne idei liniowego wzrostu gospodarki, kiedyś promowanej przez zachodnich rzeczników wolnorynkowego liberalizmu, a dziś „apostołów kreatywności” w rodzaju brytyjskiego szefa DCMS (i sprzymierzeńców jego politycznych misji) czy Richarda Floridy, które- 
go popularność ugruntowały programowe dla creative economy teksty i wykłady (Florida 2010; 2017). Właściwi danym społeczeństwom regionu popularyzatorzy tak rozumianej modernizacji imitacyjnej wchodzą w rolę pośredników między modnym dyskursem ekonomicznym a potencjalnym polem społecznym, na który taki dyskurs mógłby zostać przeszczepiony. Za sprawą działań intelektualnych fundatorów idei i ich epigonów następuje unaturalnienie pojęć kreatywności i innowacji jako czegoś oczywistego. Oznacza to, że od pracowników oczekuje się twórczego działania jako domyślnej dyspozycji. Upowszechnia się przekonanie, że model człowieka kreatywnego - charakterystyczny kiedyś dla artysty - uda się rozciągnąć nie tylko na pracowników wiedzy, ale także na inne grupy zawodowe. Jak piszą Marion von Osten i Peter Spielmann (2009: 61), ,[d]awniej kreatywność postrzegano jako coś, co powinno charakteryzować grafików, projektantów i bohemę. Dziś uważa się ją za niezbędną dla przetrwania na rynku pracy oraz $\mathrm{w}$ relacjach społecznych". Tak formułowane stanowisko promodernizacyjne staje się zbiorem samo-przez-się-zrozumiałych przeświadczeń, „rozsądnym opisem” (Garfinkel 1989: 335), intelektualną doksą (Pinto 2009: 6), a w końcu po prostu „zdrowym rozsądkiem”, który powoli zdobywa status mitu.

Co więcej, w legitymizacji logiki zachodniego kapitału akademickie i polityczne elity nie po raz pierwszy łączą perspektywę epistemologiczną z eschatologiczną (Warczok, Zarycki 2014: 134). Nowe zróżnicowania ekonomiczne i społeczne zostają przez środowiska intelektualne usankcjonowane $\mathrm{w}$ kategoriach moralnych, to jest poprzez podział dużych grup społecznych na „zbawionych” i „potępionych”. Bycie kreatywnym - twierdzi Ulrich Bröckling (2006: 517) - oznacza nieuchronne rysowanie dystynkcji, co ważne, nie tylko między „superkre- atywnym rdzeniem" a otaczającym go społecznym tłem. Nie chodzi o to, by być po prostu twórczym, ale bardziej twórczym niż inni - źródłem prawdziwie konkurencyjnej przedsiębiorczości jest dziś zdolność do ustawicznej innowacji, na co gotowi są tylko najwytrwalsi pracownicy.

Podobnie jak w przypadku mentalnościowego obciążenia syndromem homo sovieticus, można mówić tu o zaliczeniu części ludzi w poczet niekompetentnych przegranych. Jest to możliwe głównie dzięki dominującemu przekonaniu na temat istoty twórczych kompetencji. A te rozumie się bardzo szeroko - jako ontologiczną zdolność ludzkiego podmiotu, dyspozycję, która potencjalnie dotyczy wszystkich ludzi. Skoro „każdy jest kreatywny”, uchylanie się od twórczego wysiłku oznacza społeczną nieprzydatność i zaliczenie do grupy życiowych „nieudaczników”, którzy brakiem kreatywnej postawy "grzeszą" niejako na własne życzenie. Alternatywą - a właściwie „zasłużoną” i zawinioną przez sam podmiot karą - może być tylko obniżenie statusu, zubożenie i marginalizacja. Zaniechanie działania skutkuje więc niepowodzeniem osobistym i sytuuje jednostkę w roli "zacofanego" outsidera. Promotorzy dyskursu kreatywności ignorują zazwyczaj fakt, że ich oferta rozmija się z doświadczeniami dużej części współczesnych pracowników, którzy nie rozpoznają się w nowym języku i regułach gospodarowania. Podobnie jak oferta wielu psychoterapeutycznych formatów naprawczych o rzadko kwestionowanej prawomocności - na przykład coachingu i mentoringu - narracja o powszechnym i demokratycznym dostępie do twórczych kompetencji

prowadzi do wykluczenia tych osób, które w ów „kreatywny”, „twórczy” i dynamiczny schemat się nie wpisują, bądź nie chcąc, bądź nie umiejąc tego zrobić. 
Korzystanie z wolności ma - zgodnie z neoliberalną perspektywą - charakter egalitarny i każdy, kto nie chce z niej korzystać, sam stawia się poza nawiasem $\mathrm{i}$ - zasadniczo - jest to ,,jego problem”. Jednostkom takim przypisywana jest „postawa ofiary”, osoby, która unika odpowiedzialności i podejmowania wyborów, przyjmując wobec rzeczywistości bierną postawę, traktując życie jako coś, co się „przytrafia” i na co jednostka ma zasadniczo ograniczony wpływ. (Bogołębski 2014: 193)

Ani przemawiający na Litwie Chris Smith, ani forsujące ideę przemysłów kreatywnych lokalne elity nie ujawniają zatem, że w obietnicy egalitarnej wspólnoty zawartej w haśle „Kreatywność dla wszystkich!" tkwi istotny paradoks - intencja inkluzji społecznej wszystkich ludzi obdarzonych twórczym potencjałem kłóci się z realiami opartej na nierównościach i konkurencji creative economy. Pozór egalitaryzmu skrywa faktyczne dysproporcje, co oznacza, że na kreatywność „załapią się" tylko nieliczni - ludzie zdeterminowani, gotowi podjać ryzyko i przyjąć niestabilne warunki pracy, na których zbudowany jest pomysł przemysłów kultury.

To mylące wyobrażenie o rzekomym pankreatywizmie jest $\mathrm{w}$ pewnym sensie kolejnym wcieleniem doktryny elastyczności, którą w postsocjalistycznej Europie Wschodniej próbowano implementować od początku transformacji ustrojowej. Elisabeth Dunn (2017: 22), pisząc o modnych w tamtym czasie technikach „zarządzania wyzwolenia”, zwracała uwagę, że bez reszty wykluczały one z pracy tych, którym w sposób tendencyjny odmawiano zdolności do zmiany postaw, chęci do nauki czegoś nowego czy tworzenia innowacji. Dla badacza zainteresowanego „archeologią" późniejszego rozwoju dyskursu kreatywności uderzająca jest selektywność spojrzenia ówczesnych promotorów zmian. W latach 90. nowatorstwo przypisywano najczęściej tylko części zespołu restrukturyzowanych firm (głównie kadrze zarządczej i przedstawicielom handlowym), a odmawiano robotnikom odpowiedzialnym za rutynową produkcję. W przypadku tych ostatnich zupełnie ignorowano - wydawałoby się cenne w nowych warunkach - doświadczenia z okresu socjalistycznej gospodarki niedoboru, w tym pomysłowość pracowników fizycznych w rozwiązywaniu bieżących problemów. Dzięki tej „kreatywności” avant la lettre umiano radzić sobie z nagminnymi usterkami maszyn, do których brakowało części zamiennych, czy brakiem dostaw komponentów niezbędnych w podtrzymaniu bieżącej działalności wytwórczej.

Po przełomie ustrojowym robotników odgórnie zaliczono jednak do grona osób niezdatnych do elastyczności i naznaczono jako „innych” - bezużytecznych w obszarze twórczego kierowania własną pracą i z trudem poddających się nowym technikom zarządzania. „Postrzegano ich - stwierdzała Dunn (2017: 118) - jako wytwory systemu socjalistycznego, które nie potrafią dostosować się do odmiennych warunków gospodarczych, właśnie dlatego, że nie mają zdolności myślenia". Odwołując się do kulturowo skonstruowanych wyobrażeń o predyspozycjach sprzyjających zacofaniu bądź nowatorstwu, robotników fabrycznych połączono z wizerunkiem ludzi statycznych, mało wyrafinowanych i "odpornych na wiedzę". Do tego mieli być synonimem braku efektywności socjalistycznego systemu gospodarczego. Przeciwstawiano im dynamizm i rzutkość menedżerów lub pracowników działów promocji, w tamtym czasie zupełnej nowości w pejzażu odnajdujących się na wolnym rynku biznesów. Skutkowało to afirmacją „otwartej głowy", braku kompleksów w stosunku do zagranicznych partnerów, znajomości języków obcych i ogólnej przebojowości (którą często mylono z aro- 
gancją podszytą klasowymi uprzedzeniami wobec społecznych „dołów”).

Przeskok ze świata produkcji, fizycznego wysiłku i proletariackiego kolektywu do świata cyklicznych szkoleń, społecznej ruchliwości i nowoczesnych atrybutów profesjonalisty był $\mathrm{w}$ zasadzie niemożliwy. Przynależność do klasy ludowej (choć ta nazwa osadzi się w rozmowach o transformacji daleko później) oznaczała skojarzenie z niechcianą przeszłością - Polską zgrzebną, niewydolną, „socjalistyczną". Partycypacja w rzeczywistości nowych specjalistów, nawet jeżeli awans do tej grupy odbywał się w błyskawicznym tempie po zdecydowanie zbyt krótkiej trajektorii, pozwalała $\mathrm{w}$ dłuższej perspektywie zadośćuczynić zachodnim aspiracjom i pragnieniu materialnego sukcesu. A co najważniejsze, namaszczała na członka Polski „kapitalistycznej”.

\section{Inna nowoczesność}

Choć przemysły kreatywne niewątpliwie zyskały status gotowego do wdrożenia „modelu” i dziś wprost kojarzą się z praktykami implementacji całego pakietu założeń wypracowanych w krajach globalnego centrum do warunków społeczeństw rozwijających się - a tym samym narażone są na zarzut wpisania w politykę wtórnego naśladownictwa - to wyłaniająca się $\mathrm{z}$ takiego obrazu konwencjonalna matryca centroperyferyjna wydaje się niewystarczająca do opisu rzeczywistych relacji zachodzących między światem Zachodu i Europą Środkowo-Wschodnią. Obraz modernizacji naśladowczej wydaje się niepełny, jeśli pominiemy przynajmniej trzy konkurencyjne do pewnego stopnia linie polemiki z „imitacyjnym” sposobem czytania kariery dyskursu kreatywności i łączonego z nim programu rozwojowego: (1) pozbawioną kompleksów afirmację twórczych możliwości tkwiących w dawnym bloku wschodnim, (2) perspektywę rewizjonistyczną, nicującą dominujące oceny procesów modernizacyjnych z czasów komunistycznego reżimu oraz (3) optykę samokrytyczną, która w opisie zawiłego kontekstu Mitteleuropy poszukuje kompromisu między zagrożeniami orientalizmu a niedojrzałością patetycznego samozadowolenia.

Każdy z omawianych poniżej głosów uznać można za rodzaj modelowego stanowiska, reprezentatywnego dla mniejszej lub większej grupy autorów i wyrażanych przez nich opinii. Nie są to jednak jednoznaczne paradygmaty, a raczej podatne na krytykę schematy interpretacji. Jak w każdej próbie usystematyzowania odmiennych perspektyw, w obrębie których szuka się elementów typowych i powtarzalnych, trudno uniknąć tu błędów redukcjonizmu - umniejszenia siły przesłanek ściśle indywidualnych, aspirujących do odrębności i oryginalnego spojrzenia. Z pewnością wskazane tu perspektywy różnią się także pod względem rozpoznawalności, co przekłada się na odmienną siłę oddziaływania. Jedne uznać można za nadrzędne i dobrze ugruntowane, inne za peryferyjne. Jak w każdej typologii, niektóre argumenty obecne w prezentowanych $\mathrm{w}$ sposób rozłączny podejściach odnajdziemy w optykach konkurencyjnych, gdzie ich moc eksplanacyjna wykorzystywana będzie w zmieniony sposób.

1. Pierwszy głos, jak wspomniano, to stanowisko afirmatywne względem twórczego potencjału Europy Środkowo-Wschodniej. Twierdzi się tu, że mimo hegemonicznego wpływu kultur centralnych, modernizacyjne procesy na peryferiach nie ograniczają się zwykle do prostego kopiowania centrum. W ostatnim półwieczu marginalizowane kraje europejskie miały rozwijać „przemysły kultury” avant la lettre i własną „klasę kreatywną", którą 
Zachód w najlepszym przypadku drenował i podkupywał, w najgorszym ignorował lub po prostu o niej nie wiedział. Nad Wisłą za ilustrację tak rozumianego samopotwierdzenia służy zwykle dorobek polskiej szkoły filmowej, kina moralnego niepokoju, polskiej szkoły plakatu i grafiki, czterdziestoletnia działalność Mody Polskiej czy przykłady wybitnych osiągnięć architektów i lokalnych przedstawicieli wzornictwa przemysłowego (np. Jerzego Hryniewieckiego, Haliny Skibniewskiej, Zbigniewa Karpińskiego, Józefa Chierowskiego, Romana Modzelewskiego, Henryka Sztaby, Karola Śliwki, Ryszarda Bojara).

Zastosowanie postkolonialnej matrycy, poprzez którą dostrzega się wyłącznie odtwórczy charakter procesów modernizacyjnych, skrywać ma niedostrzeganą zwykle w relacji Wschód-Zachód dwukierunkowość twórczych przepływów. Ilustrują to między innymi mnożące się $\mathrm{w}$ ostatnim czasie biografie polskich artystów, architektów i urbanistów (skoncentrowane często na uświadomieniu zapomnianej roli kobiet i ich wpływu na kształtowanie europejskiej kultury) (Chomątowska 2014; Beylin 2015; Dauksza 2019; Kuźniak 2019; Stratigatos 2019). Wskazać ponadto trzeba studia nad paradoksami związanymi z nierównoczesnością procesów modernizacyjnych (np. Majewski, Rejniak-Majewska, Marzec 2014), a także przekrojowe ujęcia europejskich peryferii artystycznych (np. Piotrowski 2018; Pyzik 2018). Analizując praktyki wykluczania tych ostatnich z globalnych narracji historycznych, Piotr Piotrowski pisał (2018: 63):

możemy zauważyć, że stosunek Bułgarów, Czechów, Polaków, Rumunów, Słowaków czy Węgrów do zachodnich Europejczyków, Austriaków, Francuzów czy Niemców nie będzie relacją „innego", co najwyżej „bliskiego innego". Rzecz w tym, że „bliski inny” myśli i definiuje świat w tej samej episteme, w tym samym systemie percepcji rzeczywistości i rozumienia świata, w tych samych modelach cywilizacyjnych, tradycjach, religii, widzi siebie jako część tej samej całości, do pewnego stopnia tylko odmiennej (politycznej, językowej, kultury lokalnej). To jest fundamentalna różnica. Zachodnioeuropejskie centra kultury nie były i nie są dla artystów z Pragi czy Zagrzebia na zewnątrz ich własnego świata, jak na przykład dla artystów z Szanghaju.

Z perspektywy aktywnego artysty stanowisko Piotrowskiego potwierdzają słowa Wilhelma Sasnala (Banasiak 2017: 126-127):

z czasem zrozumiałem, że w obszarze sztuki pojęcie „centrów" i „peryferii" bardzo się zmieniło, właściwie uległo zatarciu. Coś takiego jak wyraziste centrum świata sztuki już nie istnieje. Świat sztuki permanentnie migruje, jest w ciągłym ruchu, zapala się w jednym miejscu i szybko gaśnie. (...) Przez ostatnie dwadzieścia lat geografia świata sztuki bardzo się zmieniła.

W refleksji postkolonialnej ową cyrkulację inspiracji, wiedzy i praktyk próbuje się oświetlić przy pomocy kategorii hybrydowości i opisu krzyżujących się w sposób nieoczywisty wpływów. Kulturowe procesy przejmowania czy naśladowania kreśli się nie w kategoriach hegemonicznych stosunków dominacji, ale raczej kolażu lub montowania elementów, których źródła są wielokierunkowe i trudne do jednoznacznego nazwania. Perspektywa ta próbuje przekroczyć wyobrażenie o prostej relacji kaskadowego przepływu top down, od podporządkowującego do podporządkowanego, nawet jeśli tę relację odnieść wyłącznie do sfery kultury. Nierównoczesność tych samych lub podobnych zjawisk próbuje się zdefiniować poza językiem marginalizacji i cy- 
wilizacyjnego zapóźnienia. Lepiej ma nadawać się do tego pojęcie wymiany czy „interaktywnej różnicy", będące wynikiem międzykulturowych negocjacji, także wtedy, kiedy pertraktują strony o nierównym potencjale. Te „rokowania w sprawie różnic” (Bachmann-Medick 2012: 240-241) odbywają się $\mathrm{w}$ warunkach przemieszczających się $\mathrm{z}$ Zachodu na Wschód i ze Wschodu na Zachód tradycji, samplowania motywów, których mieszany charakter został dawno zapoznany, następstw historycznego współistnienia w większych formacjach (np. takich jak Austro-Węgry), ambiwalentnych relacji między słabym a silnym czy też nacjonalizacji lub uniwersalizacji idei przynoszonych do centrum przez poszukujących lepszego życia migrantów z prowincji.

2. Druga wersja głosu polemicznego postuluje rozszerzenie horyzontu procesów rozwojowych poza umowny rok 1989 i często sama siebie nazywa perspektywą rewizjonistyczną (Gdula 2015; Zysiak 2016; Sumorok, Załuski 2017; Banasiak 2018). Definiuje się jako alternatywa dla wieloletniej dominacji modelu totalitarnego. Twierdzi - by ujać rzecz lakonicznie - że w warunkach realnego socjalizmu mieliśmy do czynienia z faktycznymi procesami modernizacyjnymi, których nie można unieważnić szantażem pamięci ofiar twardogłowego reżimu. Zdaniem zwolenników tej perspektywy, ówczesne wysiłki rozwojowe powinny być analizowane $\mathrm{w}$ alternatywnej względem paradygmatu totalitarnego optyce. W konsekwencji opowieści o PRL-u nie powinno się sprowadzać do katalogu opresji stosowanych przez powojennych despotów, historii przemocy i podporządkowania obywateli Wielkiemu Bratu zza Buga. „Lepiej Wschód dowartościować, odzyskać - bez wstydu, ale też bez nostalgii. Pół wieku przed 1989 rokiem jest oceniane tak jednoznacznie negatywnie, że nie pozwalamy sobie na zauważenie pozytywnych elementów systemu. A przecież bezrobocie było wtedy niemożliwe, różnice klasowe - minimalne, istniała solidarność społeczna", mówiła w jednym z wywiadów Agata Pyzik (Pyzik, Sulej 2015), autorka książki Biedni, ale sexy. Kulturowe zderzenia na wschodzie i zachodzie Europy (Pyzik 2018).

Dla polskiej „,archeologii” późniejszych przemysłów kreatywnych decydującym okresem jest w tej optyce dekada lat 70. W czasie „gierkowskiej modernizacji” ujawniać miały się procesy odpowiedzialne za zasadniczą zmianę w obrębie systemu socjalistycznego: upadek dominującej roli idei egalitaryzmu i kolektywizmu, wyłonienie się nowej warstwy ekspertów, przedefiniowanie roli artystów, rozwój rynku sztuki oraz uzyskanie przez klasę średnią statusu stabilizatora socjalizmu i gwaranta jego dalszego rozwoju. Co ciekawe, w retrospektywnym opisie tego okresu „rewizjoniści” używają określeń wyjętych wprost ze słownika współczesnego dyskursu kreatywności: „sprawcza jednostka”, „aktywne społeczeństwo”, „twórczość", „innowacyjność”, "skuteczność". Główną cechą roczników 70., jak wskazuje za Maciejem Gdulą Jakub Banasiak (2018: 315), miało być:

odejście od symbolicznej dominacji dyskursu egalitarnego, z klasą robotniczą $\mathrm{w}$ jego centrum, na rzecz narracji o aktywnym społeczeństwie złożonym z kreatywnych jednostek. (...) Gierkowski model socjalizmu zakładał większą innowacyjność, gotowość na współpracę międzynarodową, otwartość na problemy współczesności. Oddolne inicjatywy nie podkopywały już systemu, lecz przeciwnie - wzmacniały go. Zaczęły się liczyć pomysłowość i skuteczność.

Zmiany następowały na różnych poziomach - języka władzy, przekazów medialnych, kultury popularnej (Gdula 2015). Rezygnowano z mecenatu przemysłowego, sytuującego artystów w realiach 
wielkich zakładów przemysłowych, dożynek, defilad i rocznicowych wieców, podczas których uczestnikom przypadała rola „ornamentu z ludzkiej masy", by użyć sformułowania Siegfrieda Kracauera. Powtarzano, że prawdziwie nowoczesne społeczeństwa cenią wyobraźnię, twórcze kompetencje i odkrywczość. Stawiają na nowatorstwo i śmiało wytyczają odważne cele, potrafiąc narzucić innym wspólnotom nieznane wcześniej praktyki kulturowe.

Umieszczanego do tej pory na piedestale robotnika powoli zastępować miał „nowy mieszczanin” i jego kulturalne otoczenie - promująca alternatywne style życia telewizja, kolorowa prasa, elitarne czasopisma (wśród nich: „Architektura”, „Kino”, „Fotografia”, „Literatura na Świecie”, „Sztuka”). Jak dalej pisał Banasiak (2018: 325-326):

Uwzględnienie perspektywy rewizjonistycznej pozwala dostrzec, że modernizacja państwowego systemu sztuki, jaka dokonała się w latach 70., choć niekompletna, pociągnęła za sobą największą od powojnia zmianę społecznej roli artysty. (...) [W]łączenie sektora plastyki w gierkowski model rozwoju spowodowało, że artysta w coraz mniejszym stopniu był „robotnikiem sztuki”, który za pomocą środków wizualnych realizuje socjalistyczną utopię. Nawet pracując dla przemysłu, kreował otoczenie społeczne jako sprawcza jednostka. Plastyk, realizując program indywidualnej zaradności, mógł być również wytwórcą przedmiotów przeznaczonych na rynek, producentem dóbr luksusowych, fachowcem w dziedzinie mieszczańskiego gustu. Sam również stawał się członkiem socjalistycznej klasy średniej, podzielając nie tylko jej status materialny, ale także kapitał kulturowy, styl życia i aspiracje (...). [W] latach 70. plastyka powoli traciła nimb wyjątkowości, w który przybrała ją już to modernistyczna koncepcja dzieła sztuki, już to komunistyczny projekt społeczny. Teraz stawała się przede wszystkim towarem, rozrywką, czymś, co uprzyjemnia, nie zaś modeluje życie, w końcu - oznaką społecznego i towarzyskiego statusu.

Władza domagała się zwiększenia społecznej użyteczności sztuki i stworzenia nowych możliwości obrotu dziełami artystycznymi. Rozwijały się pierwsze prywatne galerie, gęstniała sieć Biur Wystaw Artystycznych, rosło znaczenie targów współczesnej plastyki, a drugą młodość przeżywały spółdzielnie rękodzieła, w tym słynna Cepelia. Oczekiwano, że nadzorowana przez państwo kultura wspomoże nową agendę modernizacyjną. Twórczość miała „wciskać się” do biur, fabryk i osiedli mieszkaniowych, zaspokajając nie tyle potrzeby mas, co konkretnych jednostek. Indywidualizm, jak twierdzi Gdula (2015), zyskał status słowa-klucza dekady.

3. Obok zarysowanej wyżej optyki afirmatywnej i rewizjonistycznej trzeci rodzaj polemiki z modelem „imitacyjnym” można nazwać głosem samokrytycznym. Skupia się on na wskazaniu realnych przeszkód utrudniających skuteczną implementację idei gospodarki kreatywnej w Europie Środkowo-Wschodniej, próbując jednocześnie uniknąć definiowania społecznej osobliwości regionu w kategoriach cywilizacyjnego „zacofania”. Zamiast tego w sposób możliwie wyczerpujący opisuje się tu historyczne umiejscowienie społeczeństw Mitteleuropy, kontekstualizując realnie istniejące kulturowe hamulce - a czasem celowo wdrażane praktyki oporu - które nieraz skutkowały obaleniem programów modernizacyjnych. Cytując Dipesha Chakrabarty'ego (2011: XIV), „dzielące nas różnice historyczne w istocie robią różnicę. Dzieje się tak, ponieważ żadne ludzkie społeczeństwo nie jest niezapisaną 
kartą. Uniwersalne pojęcia nowoczesności politycznej napotykają istniejące uprzednio pojęcia, kategorie, instytucje i praktyki, poprzez które dokonuje się ich przekład i odmienna konfiguracja".

Ta linia argumentacji podkreśla rozdźwięk między oryginalnym kontekstem gospodarki kreatywnej i kontekstem krajów Europy Środkowo-Wschodniej. Problematyzuje „kompatybilność” zachodniego modelu takiej gospodarki z postsocjalistycznym typem społeczeństwa i nowoczesności, które nie dają się łatwo wkomponować w „drugą”, „refleksywną” „późną” czy „płynną” nowoczesność, kategorie zaproponowane przez Daniela Bella, Ulricha Becka, Anthony'ego Giddensa czy Zygmunta Baumana (Tomić-Koludrović, Petrić 2005: 13). W optyce studiów wymienionych klasyków gospodarka kreatywna ma być dzieckiem zachodniego modelu społeczeństwa postindustrialnego i pożądanego dla modernizacyjnej rewolucji Zeitgeistu. Tak rozumiany duch dziejów łączony jest przede wszystkim z twórczą atmosferą lat 90. ubiegłego wieku, tworzoną przez wysoko wykwalifikowaną i mobilną klasę pracowników, których kompetencje wynikały z wielopokoleniowej akumulacji kapitału kulturowego.

Jeżeli przyjąć, że interpretacyjnym wytrychem gierkowskiej „dekady sukcesu” rzeczywiście był w Polsce indywidualizm (rekontekstualizowany po latach w warunkach transformacji ustrojowej), to przedstawiciele perspektywy samokrytycznej podkreślają jego zdecydowanie odmienną trajektorię od procesów indywidualizacyjnych na Zachodzie. Powtarzają za Ulrichem Beckiem, że w Europie Środkowo-Wschodniej była to przede wszystkim indywidualizacja wywołana biedą (Armuts-Individualisierung), której główna funkcja wiązała się z potrzebą dystynkcji - zaznaczeniem cywilizacyjnego dystansu wobec innych obywateli przy po- mocy zgromadzonych dóbr materialnych. W końcu przypominają, że w tym samym czasie kultura indywidualistyczna w społeczeństwach zachodniego centrum była budowana na fundamencie wartości postmaterialnych, dążeniu do samoekspresji i chęci poprawy jakości życia (Tomić-Koludrović, Petrić 2005: 15-16).

Drugi ważny rozdźwięk to stosunek do kultury fundamentu przemysłów kreatywnych. W optyce samokrytycznej dla krajów postsocjalistycznych typowy ma być niepokój o kulturę, którą rozumie się przede wszystkim jako fundament wytwarzający i chroniący narodową tożsamość. Zgodnie z takim założeniem ważną rolę w tym obszarze wciąż pełni państwo, przywiązane do wąsko pojmowanej kultury elitarnej. Jego instytucje z rezerwą podchodzą do rewaloryzacji kultury popularnej i niezobowiązującej konsumpcji dóbr symbolicznych, broniąc rozróżnienia na „komercję” i „prawdziwą sztukę”. W kontekście polityki kulturalnej Rumunii Dan Eugen Rațiu (2009: 39 [tłum. własne]) pisał:

Dyskurs publiczny w Rumunii wciąż nieustannie odwołuje się do ograniczonego, wąskiego znaczenia kultury w takim sensie, że dzieła literackie zawsze cieszyły się przewagą nad innymi formami kulturowej ekspresji, szczególnie tymi wizualnymi. Dostęp do kultury jest definiowany jako „dostęp do książek, do edukacji", co nawiązuje - znowu w sposób ograniczający - głównie do edukacyjno-kanonicznych form literackich.

Z kolei Justin O’Connor (2005: 48 [tłum. własne]), charakteryzując relacje między instytucjami kulturalnymi a państwem rosyjskim, notuje:

sztuka, dziedzictwo, [rodzime] patrymonium i kultura narodowa mogą używać technik i metod zachod- 
nich komercyjnie nastawionych instytucji kultury, ale te są [przede wszystkim] narodowymi skarbami, których tożsamościowy rdzeń musi być chroniony, z dala od komercji, konsumeryzmu i drapieżnego globalnego kapitału.

O'Connor diagnozuje wręcz wrogość władz Rosji w stosunku do kategorii „przemysły kultury”, w której rozwadniać ma się autentyczne pojęcie „artysty”. Przyjmuje się tu, że państwo gloryfikuje kulturę narodową i stosuje wobec niej postawę opiekuńczą, a jednocześnie oczekuje, że realizujące ją instytucje „odwdzięczą się" wsparciem prowadzonej przez państwo polityki. W tej optyce Rosjanie pasować mają do modelu „społeczeństwa klepsydrowego" (hour-glass society), dla którego typowy byłby rozdźwięk między działaniami kulturalnymi finansowanymi przez organy państwa i sektorem kultury niezależnej (O'Connor 2005: 54). Rosyjskie przemysły kultury odpowiadać mają raczej niezachodniemu schematowi top down, typowemu dla azjatyckich tygrysów - Singapuru, Tajwanu czy Hong Kongu. Z silnym elementem kontrolnym, strukturami oligarchicznymi, postawą protekcjonistyczną i skłonnością do instytucjonalnej centralizacji. $W$ takich warunkach trudno o budowę otwartych i przenikających się wzajemnie środowisk artystycznych, ukształtowanie płynnych sieci pracowników identyfikujących się jako klasa kreatywna (lub choćby „robotnicy sztuki"). Równie trudno o wychowanie prawdziwie różnorodnej i „wyrobionej” widowni, co w rzeczywistości zachodniej uważa się za czynniki sprzyjające rozwojowi przemysłów kreatywnych.

Na Zachodzie wszystkie te elementy miały się wykształcić w zupełnie innym kontekście. Zwraca się uwagę, że już w połowie ubiegłego wieku kulturę przestano łączyć z zadaniami na rzecz etnicznie pojmowanej wspólnoty narodowej i wąsko zakrojonej polityki tożsamości. Uwagę przekierowano na wyzwania modernizacyjne innego typu - wsparcie multikulturalizmu czy rewitalizację zaniedbanych dzielnic w obszarach metropolitarnych. W latach 80. idea przemysłów kultury służyć miała politycznej i zawodowej mobilizacji młodzieży, "sklejaniu” lokalnych społeczności, pobudzaniu indywidualnej ekspresji czy tworzeniu miejsc pracy $\mathrm{w}$ zdeindustrializowanej gospodarce (Pratt 2009: 11). Z tych wszystkich powodów nie może zatem dziwić, że - jak ujmuje to O'Connor (2005: 47 [tłum. własne]) - „dyskurs «przejścia» [transition] używany na Zachodzie widzi w rosyjskim niepokoju o tożsamość wyłącznie balast, który należy porzucić".

\section{Kreatywność usytuowana}

Wsłuchując się w każdy z prezentowanych wyżej "głosów", widać, że implementacja idei gospodarki kreatywnej - jeśli traktować ją wieloaspektowo - wpisuje się w szersze kulturowe procesy translacyjne, opisywane w ramach studiów nad „zwrotem translatologicznym" (translational turn) (Snell-Hornby 2009; Bachmann-Medick 2012). Procesy te wiążą się z rozszerzonym pojęciem przekładu, identyfikowanego już nie tylko z paradygmatem lingwistyczno-tekstualnym (upraszczając - tłumaczeniem języków i tekstów), ale traktowanym jako „niezbywalna praktyka w świecie wzajemnych zależności i usieciowień" (Bachmann-Medick 2012: 281). Według wielu badaczy "stosunki translatoryczne" stają się pierwszorzędną cechą społeczeństwa nowoczesnego, a przekład urasta do jednego z głównych konceptów nauk społecznych i humanistycznych związanych z takimi kategoriami jak: „wędrujące pojęcia” (travelling concepts) (Bal 2012), „podróżująca teoria” (traveling theory) (Said 1983), „przemieszczenie-jako-przekład" (displacement-as-translation) 
(Chakrabarty 2014), „kulturowy transfer” (cultural transfer) i „niewierne przywłaszczenie” (faithless appropriation) (Bachmann-Medick 2014).

W kontekście gospodarki kreatywnej dobrą ilustracją lokalnych strategii translacyjnych jest wschodnioeuropejska odpowiedź na powszechne trendy postindustrializacyjne - zanikanie znaczenia sektora przemysłowego i otwarcie na oddziaływania gospodarki globalnej. Począwszy od lat 90. ubiegłego wieku wiele państw regionu przekuło płynące z Zachodu idee społeczeństwa opartego na wiedzy w ambiwalentny program „boomu edukacyjnego" (Musiał 2013: 229). Zaowocowało to rozrostem niepublicznego szkolnictwa wyższego, które wprawdzie podniosło ogólny współczynnik skolaryzacji, ale jednocześnie przyczyniło się do dewaluacji wiedzy specjalistycznej i inflacji dyplomów akademickich, które gwarantować miały wejście na rynek nowej armii „innowacyjnych” pracowników. W czasach transformacji systemowej program masowego nauczania unaturalnił pojęcie wiedzy i kreatywności jako czegoś oczywistego (ucieleśnieniem tego myślenia pozostają hasła "kształcenia ustawicznego" $\mathrm{i}$ „,uczenia się przez całe życie”), podobnie jak stało się to w przypadku innych słów-kluczy ze słownika nowych strategii zarządczych, na przykład „,kapitału ludzkiego”, „podmiotowości” czy „sprawczości”. Dyskusyjne pozostaje, na ile wszystkie te kategorie stały się porządkiem samej rzeczywistości, dla której stanowiłyby fundament jej społecznej organizacji, a na ile pozostają tylko publicznie mobilizowanym zasobem wyznaczania celów rozwojowych i interpretacji pożądanych przeobrażeń mentalności obywateli.

Inny przykład dotyczy strategii translacyjnych uruchomionych przez proces akcesyjny do Unii Europejskiej, w ramach którego demokratyzacja twórczych kompetencji stała się obowiązkową lekcją, której odrobienie miało zaświadczać o przynależności do klubu nowoczesnych społeczeństw Zachodu. Jak twierdzi Mike Bal (2012: 54) - jedna z klasyków translational turn - „pojęcia nigdy nie są po prostu opisowe, lecz również projektujące i normatywne. Używanie ich wywiera zatem określone skutki". Zazwyczaj organizują rzeczywistość w zupełnie nowy sposób, fundując zmiany, których niejednoznaczny sens ujawnia się dopiero po długim czasie. Ich przekład - nawet w sposób niezamierzony - może stać się medium misyjnego nawracania i sprzyjać powstaniu nowych, neokolonialnych zależności (Bachmann-Medick 2012: 290). Dobrze ilustruje to historia społeczeństw Europy Środkowo-Wschodniej, których zabiegom o pełnoprawne członkostwo w Unii towarzyszyło między innymi oczekiwanie zmiany relacji między sztuką i przedsiębiorczością, usługami publicznymi i biznesem. Zrodziło to nowe formy instrumentalizacji kultury i wygenerowało biurokratyczny sposób rozumienia twórczości artystycznej, w tym tak dotkliwie odczuwaną dzisiaj przez sektor kreatywny i artystów "grantozę".

W logice „projektowej” - konieczności aplikowania o środki finansowe w ramach ogłaszanych systematycznie programów powiązanych z celami polityk publicznych - konieczność utrzymywania konwencjonalnie rozumianych zadań instytucji kultury uznano za typowe dla kontekstu postsocjalistycznego „obciążenie”. Jednocześnie w promowanym alternatywnie języku „przydatności” i „opłacalności” kultury z pracującego $\mathrm{w}$ tym sektorze środowiska próbowano zdjąć odium zachłannych konsumentów środków budżetu państwa. Branże kreatywne miały stać się trampoliną dla ekonomicznego wzrostu, generatorem nowych miejsc pracy i impulsem do rewitalizacji przestrzeni miejskich. Część arty- 
stów zaczęła z przekonaniem reprodukować retorykę ekonomii kultury i uczestniczyć w procedurach aplikacyjnych, przekonana o słuszności i bezalternatywności idei przemysłów kreatywnych. Dla innych podążanie za hasłem „kultura się liczy” wiązało się z koniecznością założenia maski lojalnego współpracownika procedur aplikacyjnych i - nierzadko - zgodą na udział w praktykach udawania, które umożliwiały podstawowe działanie (a często po prostu przetrwanie) $\mathrm{w}$ ramach obowiązujących reguł gry. Wielu twórcom pozwalało to podzielić aktywność zawodową między projekty ściśle komercyjnie, zadania realizowane $\mathrm{w}$ zgodzie $\mathrm{z}$ wytycznymi dyskursu instytucjonalnego oraz „nieprzydatne” z punktu widzenia logiki „dotacyjnej” realizacje niezależne, które nie mogły liczyć na uzyskanie finansowania przez agendy dominujących polityk publicznych.

Przykładem ilustrującym pożądany wśród nowych członków wspólnoty europejskiej pragmatyzm pozostają decyzje rządów Estonii z pierwszej dekady lat 2000. Ochocze przyjęcie idei gospodarki kreatywnej (tłumaczonej jako loomemajandus) posłużyło tu za podstawę strategii wyznaczenia alternatywnych celów modernizacyjnych. Zakładano, że odwołanie do „kreacji” (loome) i „kreatywności” pozwoli zdystansować się od skojarzeń z typowymi cechami konwencjonalnie pojmowanej „,kultury" i "sztuki": elitarnością, tradycjonalizmem i stagnacją. Miało to także pomóc - jak wyobrażały sobie progresywne elity - przeciągnąć Estonię w stronę „rozwiniętego świata”, łącząc lokalny potencjał z innowacją, nowością i nastawieniem reformatorskim (Mäe 2015: 82). Oficjalne dokumenty przygotowywane przez estońską administrację forsowały przekonanie o doniosłej roli kreatywności we współczesnym świecie i dowodziły, że natura pojęć „kultura”, „kreatywność”, „wiedza” i „go- spodarka" nie jest stabilna. Jak pisała Doris Bachmann-Medick (2012: 327), „przekład nie jest wobec tego tylko transferem, ale pokonywaniem oporów, ustawiczną przemianą". Skłania to do uznania, że podstawą dyskursu biurokratycznego dominującego w ówczesnej polityce Tallina pozostaje nieusuwalna niejasność, brak ścisłości i niekonsekwencja w budowaniu przekazu, gdzie „kultura może raz oznaczać kulturę narodową, wytwór przemysłów kultury albo kulturę organizacyjną - tak jak pracownik kreatywny może być dyrygentem narodowej orkiestry, dyrektorem artystycznym w agencji reklamowej albo kuratorem galerii sztuki" (Mäe 2015: 83 [tłum. własne]).

\section{Zakończenie}

Podejmując wysiłek interdyscyplinarnych badań gospodarki kreatywnej, łatwo może okazać się, że wszelką aktywność upowszechniania przemysłów kreatywnych należałoby traktować jako kontinuum rekontekstualizacji, wymuszonej kontaktem z określonym tłem społecznym. Podróż przekonania o „użyteczności” kultury i rentowności gospodarki kreatywnej z jednego kontekstu do innego nigdy nie jest transferem gotowego przekazu - przejście od jednej zbiorowości do innej zawsze tworzy nowe znaczenia. Przemieszczenie każdego elementu tych zasobów oznacza odmienny sposób jego rozumienia, niekiedy nadanie mu przeciwnych znaczeń oraz - co za tym idzie - kształtowanie alternatywnych sposobów jego użycia i praktycznego wykorzystania.

W refleksji badaczy zachodnich nie brakuje interdyscyplinarnych i jednocześnie krytycznych prac dotyczących gospodarki kreatywnej. Wystarczy wskazać studia Geralda Rauniga, Gene'a Raya i Ulfa Wuggeniga (2011), Dana-Eugena Rațiu (2011), Mar- 
kusa Metza i Georga Seeßlena (2014) czy - wspomnianych wyżej - Andy'ego Pratta (2009), Angeli McRobbie (2016) i Andreasa Reckwitza (2017). Szczególny kontekst społeczeństw Europy Środkowo-Wschodniej powoduje, że inspiracje płynące z zachodnich analiz gospodarki kreatywnej powinny być wykorzystywane szczególnie ostrożnie, a samo postępowanie badawcze nie może być odtwórczym powtórzeniem wcześniejszych procedur z użyciem dobrze znanego zaplecza teoretycznego.

\section{Bibliografia}

Angermuller Johannes (2014) Poststructuralist Discourse Analysis. Basingstoke: Palgrave Macmillan.

Bachmann-Medick Doris (2012) Cultural Turns. Nowe kierunki w naukach o kulturze. Przełożyła Krystyna Krzemieniowa. Warszawa: Opficyna Naukowa.

Bachmann-Medick Doris (2014) From Hybridity to Translation: Reflection on Travelling Concepts [w:] Doris Bachmann-Medick, eds., The Trans/National Study of Culture. A Translational Perspective. Berlin/Boston: de Gruyters, s. 119-136.

Bal Mike (2012) Wędrujące pojęcia w naukach humanistycznych. Przełożyła Marta Bucholc. Warszawa: Narodowe Centrum Kultury.

Banasiak Jakub (2017) 15 stuleci. Rozmowa z Wilhelmem Sasnalem. Wołowiec: Wydawnictwo Czarne.

Banasiak Jakub (2018) Prześniona dekada. Próba modernizacji państwowego systemu sztuki 1971-1980 [w:] Dorota Monkiewicz, red., Awangarda i państwo. Łódź: Muzeum Sztuki w Łodzi, s. 312-326.

Beylin Marek (2015) Ferwor. Życie Aliny Szapocznikow. Kraków, Warszawa: Wydawnictwo Karakter, Muzeum Sztuki Nowoczesnej w Warszawie.

Bogołębski Tomasz (2014) Coaching w optyce rządomyślności - próba krytycznej analizy zjawiska [w:] Marek Czyżewski i in.,
W obliczu zachodniej oferty transferu gotowych pomysłów analitycznych potrzebna jest kreatywna, nomen omen, reinterpretacja zachodniego dyskursu teoretycznego oraz aktywne poszukiwanie oryginalnych pojęć i konceptów dostosowanych do lokalnych warunków i specyfiki krajów regionu. Konieczne jest nie proste przyswojenie, ale transformacja i nieustanne negocjowanie słownika, który umożliwi pogłębione zrozumienie ideologicznego ładunku pojęcia 'creative economy'.

red., Dyskurs elit symbolicznych. Warszawa: Wydawnictwo Sedno, s. 173-196.

Bröckling Ulrich (2006) On Creativity: A brainstorming session. „Educational Philosophy and Theory”, vol. 38, no. 4, s. 513-521.

Bührmann Andrea D., Schneider Werner (2008) Vom Diskurs zum Dispositiv. Eine Einführung in die Dispositivanalyse. Bielefeld: transcript.

Chakrabarty Dipesh (2011) Prowincjalizacja Europy. Myśl postkolonialna i różnica historyczna. Przełożyli Dorota Kołodziejczyk, Tomasz Dobrogoszcz, Ewa Domańska. Poznań: Wydawnictwo Poznańskie.

Chakrabarty Dipesh (2014) Place and Displaced Categories, or How We Translate Ourselves into Global Histories of the Modern [w:] Doris Bachmann-Medick, ed., The Trans/National Study of Culture. A Translational Perspective. Berlin/Boston: de Gruyters, s. $53-68$.

Chang Ha-Joon (2016) Źli samarytanie. Mit wolnego handlu i tajna historia kapitalizmu. Przełożyli Michał Sutowski, Barbara Szelewa. Warszawa: Wydawnictwo Krytyki Politycznej.

Chomątowska Beata (2014) Lachert i Szanajca. Architekci awangardy. Wołowiec: Wydawnictwo Czarne.

Dauksza Agnieszka (2019) Jaremianka. Kraków: Wydawnictwo Znak. 
Dunn Elizabeth (2017) Prywatyzujac Polskę. O bobofrutach, wielkim biznesie i restrukturyzacji pracy. Przełożył Przemysław Sadura. Warszawa: Wydawnictwo Krytyki Politycznej.

Florida Richard (2010) Narodziny klasy kreatywnej. Przełożyli Tomasz Krzyżanowski, Michał Penkala. Warszawa: Narodowe Centrum Kultury.

Florida Richard (2017) The New Urban Crisis. How Our Cities Are Increasing Inequality, Deepening Segregation, and Failing the Middle Class - And What We Can Do About It. New York: Basic Books.

Foucault Michel (2002) Porządek dyskursu. Przełożył Michał Kozłowski. Gdańsk: słowo/obraz terytoria.

Garfinkel Harold (1989) Aspekty problemu potocznej wiedzy o strukturach społecznych. Przełożyła Dorota Lachowska [w:] Zdzisław Krasnodębski, red., Fenomenologia i socjologia. Zbiór tekstów. Warszawa: Państwowe Wydawnictwo Naukowe, s. 324-342.

Gdula Maciej (2015) Odważ się być średnim! Genealogia i przyszłość polskiej klasy średniej. „Krytyka Polityczna”, nr 42, s. $83-132$.

Jasiecki Krzysztof (2016) Nowa peryferyjność w perspektywie różnorodności kapitalizmu. Przykład posocjalistycznych państw Unii Europejskiej [w:] Tomasz Zarycki, red., Polska jako peryferie. Warszawa: Wydawnictwo Naukowe Scholar, s. 51-72.

Judt Tony (2013) Zapomniany wiek dwudziesty. Retrospekcje. Przełożył Paweł Marczewski. Warszawa: Wydawnictwo Uniwersytetu Warszawskiego.

Kornai János (1992) The Socialist System. The Political Economy of Communism. Oxford: Clarendon Press.

Kuźniak Angelika (2019) Stryjeńska. Diabli nadali. Wołowiec: Wydawnictwo Czarne.

Langer Antje, Nonhoff Martin, Reisigl Martin (2019) Diskursanalyse und Kritik. Wiesbaden: Springer VS.

Leszczyński Adam (2013) Skok w nowoczesność. Polityka wzrostu w krajach peryferyjnych 1943-1980. Warszawa: Wydawnictwo Krytyki Politycznej.

Martilla Thomas (2016) Post-Foundational Discourse Analysis. From Political Difference to Empirical Research. Basingstoke: Palgrave Macmillan.
Mäe Rene (2015) The Creative Industries: a discourse-theoretical approach. „International Review of Social Research”, vol. 5, no. 2, s. $78-87$.

Majewski Tomasz, Rejniak-Majewska Agnieszka, Marzec Wiktor, red. (2014) Migracje modernizmu. Nowoczesność i uchodźcy. Łódź, Warszawa: Stowarzyszenie Inicjatyw Miejskich Topografie, Narodowe Centrum Kultury.

McRobbie Angela (2016) Be Creative. Making a Living in the New Culture Industries. Cambridge: Polity Press.

Metz Markus, Seeßlen Georg (2014) Geld frisst Kunst, Kunst frisst Geld. Ein Pamphlet. Berlin: Suhrkamp.

Musiał Wojciech (2013) Modernizacja Polski. Warszawa: Fundacja Nauki Polskiej.

Nowak Andrzej W. (2016) Tajemnicze zniknięcie Drugiego Świata. O trudnym losie pótperyferii [w:] Tomasz Zarycki, red., Polska jako peryferie. Warszawa: Wydawnictwo Naukowe Scholar, s. 86-104.

Nowicka Magdalena (2016) O użyteczności kategorii dyspozytywu w badaniach społecznych. "Przegląd Socjologii Jakościowej”, t. 12 , nr 1, s. 170-191.

O'Connor Justin (2005) Creative Exports. Taking cultural industries to St Petersburg. "I International Journal Policy", vol. 11, no. 1 , s. $45-60$.

Osten von Marion, Spielmann Peter (2009) Produkcja kultury w epoce kapitalizmu kognitywnego. Przełożyli Anna Szyjkowska-Piotrowska, Michał Piotrowski [w:] Katarzyna Chmielewska, Kuba Szreder, Tomasz Żukowski, red., Czytanki dla robotników sztuki. Kultura nie dla zysku. Warszawa: Fundacja Bęc Zmiana, s. 59-67.

Pinto Louis (2009) Le café du commerce des penseurs. Á propos de la doxa intellectualle. Paris: Savoir/Agir.

Piotrowski Piotr (2018) Globalne ujęcie sztuki Europy Wschodniej. Poznań: Dom Wydawniczy Rebis.

Polyák Lenente (2010) Wyzwalajaca rama. Nowoczesne przestrzenie pracy i inspiracji. Przełożył Michał Choptiany. „Autoportret", nr 1(30), s. 30-33.

Pratt Andy C. (2009) Policy Transfer and the Field of the Cultural and Creative Industries: What Can Be Learned from Europe? [w:] Lily Kong, Justin O'Connor, eds., Creative Economies, Cre- 
ative Cities. Asian-European Perspectives. New York: Springer, s. 9-23.

Pruchnik Kamil, Zowczak Jakub (2016) Polska transformacja w kontekście pułapki średniego dochodu [w:] Mirosław Geise, Jarosław Oczki, Dariusz Piotrowski, red., Transformacja gospodarcza w Polsce. Bydgoszcz: Wydawnictwo Uczelniane Wyższej Szkoły Gospodarki, s. 11-20.

Pyzik Agata (2018) Biedni, ale sexy. Kulturowe zderzenia na wschodzie $i$ zachodzie Europy. Przełożył Miłosz Wojtyna. Gdańsk: Wydawnictwo W podwórku.

Pyzik Agata, Sulej Karolina (2015) Jesteśmy biedni, ale sexy! „,Wysokie Obcasy" [dostęp 26 września 2020 r.]. Dostępny w Internecie: https:// www.wysokieobcasy.pl/wysokie-obcasy/1,53662,18036406,_Agata_ Pyzik_z_Europy_Wschodniej_Jestesmy_biedni_html_.

Radło Mariusz-Jan, Ciesielska Dorota (2013) Polska w pułapce średniego dochodu. Perspektywy konkurencyjności polskiej gospodarki i regionów. Warszawa: Difin.

Rațiu Dan-Eugen (2009) Cultural Policy and Values: Intrinsic versus Instrumental? The Case of Romania. "The Journal of Arts Management, Law, and Society", vol. 39, no. 1, s. 24-44.

Rațiu Dan-Eugen (2011) Artistic Critique and Creativity: How Do Artists Play in the Social Change?. "Studia Ubb. Philosophia”, vol. 3, no. 56, s. $27-49$.

Raunig Gerald, Gene Ray, Wuggenig Ulf, eds. (2011) Critique of Creativity: Precarity, Subjectivity and Resistance in the 'Creative Industries'. London: MayFlyBooks.

Reckwitz Andreas (2017) Odkrycie kreatywności. O procesie społecznej estetyzacji. Przełożyły Katarzyna Kończal, Zofia Sucharska. Warszawa: Narodowe Centrum Kultury.

Said Edward (1983) Traveling Theory [w:] tegoż, The World, the Text, and the Critic. Cambridge MA: Harvard University Press, s. 226-247.

Sieroń Arkadiusz (2019) Czy Polska wpadła w pułapkę średniego dochodu?. „Optimum. Economic Studies”, nr 2(96), s. 53-68.

Snell-Hornby Mary (2009) What's in a Turn? On Fits, Starts and Writhings in Recent Translation Studies. „Translation Studies” no. 2(1), s. 41-51.

Stanek Łukasz (2015a) Architects from Socialist Countries in Ghana (1957-67): Modern Architecture and Mondialisation. „Journal of the Society of Architectural Historians", vol. 74, no. 4, s. $416-442$.
Stanek Łukasz (2015b) Mobilities of Architecture in the Global Cold War: From Socialist Poland to Kuwait and Back. „International Journal of Islamic Architecture", vol. 4, no. 2, s. 365-398.

Stratigatos Despina (2019) Gdzie sq architektki? Przełożyła Agnieszka Rasmus-Zgorzelska. Warszawa: Fundacja Centrum Architektury.

Sudjic Deyan (2015) Kompleks gmachu. Architektura władzy. Przełożyła Agnieszka Rasmus-Zgorzelska. Warszawa: Centrum Architektury.

Sumorok Aleksandra, Załuski Tomasz, red. (2017) Socrealizmy i modernizacje. Łódź: Akademia Sztuk Pięknych.

Szomburg Jan (2014) Rozwój kulturowo-mentalny to nasze największe wyzwanie modernizacyjne w następnych 25 latach [w:] Jan Szomburg, red., Jaka modernizacja Polski: od budowy infrastruktury do nowych postaw i zachowań? Gdańsk: Instytut Badań nad Gospodarką Rynkową, s. 7-9.

Tokarczuk Olga (2018) Zielone dzieci [w:] tejże, Opowiadania bizarne. Kraków: Wydawnictwo Literackie, s. 10-44.

Tomić-Koludrović Inga, Petrić Mirko (2005) Creative Industries in Transition: Towards a Creative Economy? [w:] Nada Švob-Đokić, ed., The Emerging Creativer Industries in Southeastern Europe. Zagreb: Institute for International Relations, s. 7-23.

Warczok Tomasz, Zarycki Tomasz (2014) (Ukryte) zaangażowanie $i$ (pozorna) neutralność: strukturalne ograniczenia rozwoju socjologii krytycznej w warunkach pótperyferyjnych. "Stan Rzeczy”, nr 1(6), s. 129-158.

Zarycki Tomasz (2014) Innowacjonizm jako legityzmizacja. Dyskursy innowacji, gospodarki opartej na wiedzy, społeczeństwa informacyjnego i pokrewne w perspektywie krytycznej. "Zarządzanie Publiczne", nr 1(27), s. 20-34.

Zarycki Tomasz (2015) Modernizacja kulturowa i psychologiczna jako ideologia inteligenckiej hegemonii. „Przegląd Socjologiczny”, t. 64 , nr 2, s. $45-68$.

Zarycki Tomasz (2016) Polska jako peryferie stykowe [w:] Tomasz Zarycki, red., Polska jako peryferie. Warszawa: Wydawnictwo Naukowe Scholar, s. 105-147.

Zysiak Agata (2016) Punkty za pochodzenie. Powojenna modernizacja $i$ uniwersytet $w$ robotniczym mieście. Warszawa: Zakład Wydawniczy Nomos. 


\title{
Cytowanie
}

Franczak Karol (2020) Kreatywność eksport-import. Interdyscyplinarne badania gospodarki kreatywnej w Europie Środkowo-Wschodniej. „Przegląd Socjologii Jakościowej”, t. 16, nr 4, s. 60-84 [dostęp dzień, miesiąc, rok]. Dostępny w Internecie: 〈www.przegladsocjologiijakosciowej.org>. DOI: http://dx.doi.org/10.18778/1733-8069.16.4.04

\section{Export-Import Creativity: Interdisciplinary Research on Creative Economy in Central and Eastern Europe}

\begin{abstract}
Following the development of interdisciplinary analyses of the creative economy in the reflection of Western societies, the paper poses a question about the specificity of implementing this idea in Central and Eastern Europe. The author confronts the mythology of creative industries with the complex social and political context of the region's countries, and tries to determine whether specific public policies have a comparable result when applied in different social, cultural, and political conditions. The problematization of the 'compatibility' of the innovationist discourse with a type of society and modernity different from the Western one serves to reflect on the universal phenomenon of the reception of Western modernization narratives as well as strategies of their assimilation, resistance, or new reconstructions.
\end{abstract}

Keywords: creative economy, Central and Eastern Europe, modernization discourse, center-periphery relations, translational turn 